\title{
Wpływ kompetencji przedsiębiorczych naukowców na współpracę nauki i biznesu
}

\author{
Monika Jakubiak \\ Zakład Zarzq̨dzania, Wydział Ekonomiczny, Uniwersytet Marii Curie-Skłodowskiej \\ Paweł Chrapowicki
}

Wydział Zarzadzania, Uniwersytet Warszawski

\begin{abstract}
Współpraca nauki i biznesu nabiera w obecnych czasach coraz większego znaczenia. Zmieniająca się rola szkoły wyższej powoduje konieczność nawiązywania współpracy z otoczeniem gospodarczym, w tym w zakresie komercjalizacji wyników badań naukowych. Problematyka prezentowanego artykułu dotyczy kompetencji przedsiębiorczych naukowców, rozpatrywanych w kontekście współpracy między szkołą wyższą a przedsiębiorcami. Celem przeprowadzonego badania była próba identyfikacji kompetencji naukowców, które determinują podjęcie oraz realizację współpracy z przedstawicielami przedsiębiorstw. Badanie empiryczne przeprowadzono w 2017 r. w Lublinie za pomocą metody case study, z zastosowaniem obserwacji bezpośredniej oraz wywiadu. Analiza wyników badania pozwoliła na konceptualizację modelu kompetencji przedsiębiorczych naukowców - aktywnych uczestników procesu komercjalizacji.
\end{abstract}

Słowa kluczowe: kompetencje przedsiębiorcze naukowców, komercjalizacja wyników badań naukowych, współpraca nauki i biznesu, rola szkoły wyższej, interesariusze uczelni

\section{Wprowadzenie}

Współpraca nauki i biznesu nabiera w obecnych czasach coraz większego znaczenia. W warunkach gospodarki opartej na wiedzy na znaczeniu zyskuje bowiem zarówno wiedza, jak i kompetencje organizacji i jej pracowników. Niniejszy artykuł wpisuje się w dyskurs dotyczący kompetencji przedsiębiorczych, które w literaturze przedmiotu są analizowane w kontekście przedstawicieli różnych grup 
społecznych, tj. studentów i absolwentów, pracowników przedsiębiorstw, a także naukowców.

Problematyka prezentowanego artykułu dotyczy kompetencji przedsiębiorczych naukowców, rozpatrywanych w kontekście współpracy między szkołą wyższą a przedsiębiorcami. Celem przeprowadzonego badania była próba identyfikacji kompetencji naukowców, które determinują podjęcie oraz realizację współpracy z przedstawicielami przedsiębiorstw.

\section{Kompetencje przedsiębiorcze - ujęcie literaturowe}

W literaturze przedmiotu podkreśla się obecnie, że to wartości niematerialne, w tym wiedza i umiejętność jej praktycznego wykorzystania, mogą się przyczynić do uzyskania przez przedsiębiorstwo trwałej przewagi konkurencyjnej (Dyduch, 2004; Juchnowicz, 2004; Sajkiewicz, 2004). Szczególnego znaczenia nabierają kompetencje organizacji, w literaturze rozpatrywane w dwóch kontekstach.

W szerszej perspektywie jest podkreślany wpływ kompetencji organizacji na budowanie przewagi konkurencyjnej przedsiębiorstwa na rynku. Kompetencje są wówczas interpretowane jako połączenie specyficznej wiedzy, doświadczeń oraz umiejętności wykształconych w organizacji. Zwolennicy podejścia badawczego, zwanego perspektywą kompetencyjną (competence based perspective), skupiają się przede wszystkim na analizie wnętrza organizacji, starając się tam właśnie znaleźć źródła przewagi konkurencyjnej opartej na posiadanych kompetencjach (Wernerfelt, 1984).

W węższym podejściu do kompetencji organizacji traktuje je w kontekście kompetencji pracowników. Uznaje się, że kompetencje indywidualne poszczególnych członków organizacji składają się na potencjał pracy jako całości. Z kolei indywidualny potencjał pracy każdego pracownika tworzą jego wiedza i umiejętności zawodowe (tzw. kompetencje twarde) oraz predyspozycje, cechy osobowości, motywacja oraz pełnione role społeczne (tzw. kompetencje miękkie) (Olczak, Kołodziejczyk-Olczak, 2006). Rozpatrywany w tym kontekście potencjał kompetencyjny organizacji stanowi tym samym iloczyn indywidualnych potencjałów pracy, wyrażony liczbą osób zatrudnionych w firmie oraz indywidualnego czasu pracy (Sitko-Lutek, 2007).

W literaturze toczy się obecnie dyskurs na temat różnic między kompetencjami a umiejętnościami. I tak, zdaniem T. Oleksyna (2006), kompetencje pracownicze są pojęciem szerszym i obejmującym, oprócz umiejętności, także wiedzę i wykształcenie, doświadczenie, postawy i zachowania, uzdolnienia, predyspozycje, motywację oraz cechy psychofizyczne. P. Juceviciene i D. Lepaitte ( 2004) wprowadzili holistyczny model kompetencji, w którym wskazują, że kompetencje 
są uwarunkowane indywidualną wiedzą i umiejętnościami, jak również motywami, charakterystykami osobistymi oraz wartościami. Podobnego zdania jest A. Rakowska (Rakowska, Sitko-Lutek, 2000), wg której umiejętności są związane z zachowaniami jednostki jako reakcjami na płynące z otoczenia bodźce i kształtują posiadane przez daną osobę kompetencje. Zdaniem badaczy przedmiotu (Argyle, 1967; Prien, 1977; Boyatzis, 1982), posiadanie konkretnych umiejętności nie gwarantuje jednak, że pracownik jest kompetentny. Aby tak było, powinien bowiem mieć predyspozycje umożliwiające mu przełożenie umiejętności na skuteczne działanie (Antonacopoulou, Fitzgerald, 1996).

Koncepcja kompetencji przedsiębiorczych została zapoczątkowana przez R.A. Boyatzisa (1982), który na podstawie badań realizowanych w przedsiębiorstwach stworzył model kompetencji, jakie powinni mieć skuteczni menedżerowie. Koncepcja ta została następnie przeniesiona na grunt przedsiębiorczości i poddana próbom empirycznej weryfikacji (Glinka, Gudkova, 2011). Obecnie, zdaniem B. Glinki i S. Gudkovej (2011), można wyróżnić pięć podstawowych elementów związanych z osobą przedsiębiorcy (wiedza, motywy, cechy osobowości, poczucie własnej skuteczności oraz mechanizmy poznawcze), określanych jako wewnętrzne czynniki warunkujące powodzenie przedsiębiorcy na rynku, czyli kompetencje przedsiębiorcze.

Problematyka niniejszego artykułu dotyczy kompetencji przedsiębiorczych naukowców oraz czynników determinujących ich współpracę z przedstawicielami biznesu w procesie komercjalizacji wyników badań naukowych. Na podstawie analizy literatury przedmiotu przyjęto, że skuteczność w procesie podejmowania i realizacji wspólnych działań w zakresie komercjalizacji jest warunkowana czynnikami zewnętrznymi (niezależnymi od danej jednostki naukowej) oraz wewnętrznymi (zależnymi od uczelni i jej uczestników). Wśród czynników wewnętrznych warto wyróżnić zwłaszcza kompetencje naukowców, będące wypadkową określonych właściwości jednostki, takich jak cechy osobowości, wyznawane wartości, postawy, kompetencje, motywacje, jej wiedza i przygotowanie (w procesie edukacji, ale także w wyniku gromadzonych doświadczeń), oraz oddziaływania środowiska (jak dorastanie w przedsiębiorczej rodzinie) (Kwiatkowski, 2002; Olearnik, 2007; Glinka, Gudkova, 2011).

\section{Komercjalizacja wyników badań rolą współczesnej szkoły wyższej}

Przedsiębiorczość jest pojęciem często podejmowanym w literaturze, jednak ze względu na jej złożoność - nie stworzono do tej pory jednej definicji wyczerpującej wszystkie aspekty tego zjawiska. Zazwyczaj określa się ją jako poszukiwanie, 
wykorzystywanie oraz tworzenie szans (Timmons, 1999; Kwiatkowski, 2002). Może być identyfikowana jako skłonność do podejmowania i prowadzenia własnej działalności gospodarczej, ale traktowana szerzej może także cechować jednostki podejmujące aktywne działania i poszukujące szans w ramach już istniejących podmiotów gospodarczych lub działające aktywnie na rzecz swojego środowiska (Glinka, Gudkova, 2011).

Przemianom społeczno-gospodarczym towarzyszą zmiany w zakresie zainteresowań przedsiębiorców. Obecnie pojawiają się nowe formy przedsiębiorczości, w tym dynamicznie rozwijająca się przedsiębiorczość na styku nauki i biznesu nowe formy przedsiębiorczości intelektualnej, technologicznej, przedsiębiorczości wiedzy (Cieślik i in., 2011).

Wraz ze zmieniającą się rolą szkoły wyższej, w literaturze przedmiotu szeroko jest podejmowana problematyka przedsiębiorczości akademickiej. Jest ona różnie definiowana przez badaczy. W wąskim ujęciu definiuje się ją jako zakładanie przedsiębiorstw (najczęściej spółek typu spin-off lub spin-out) przez pracowników naukowych, studentów lub szkoły wyższe. W szerszym kontekście przedsiębiorczość akademicka obejmuje wszelkie działania uczelni związane $\mathrm{z}$ oferowaniem wiedzy i jej wykorzystaniem komercyjnym (Matusiak, Zasiadły, 2005). W tym kontekście na znaczeniu zyskuje aktywność uczelni w kierunku nawiązywania współpracy z otoczeniem gospodarczym, w tym zwłaszcza w zakresie komercjalizacji wyników badań naukowych (Stawasz, 2007; Poznańska, 2014).

W procesie komercjalizacji szczególną rolę odgrywają szkoły wyższe, stanowiące istotne źródło nowej wiedzy. W literaturze przedmiotu podkreśla się, że obecnie szkoły wyższe odgrywają istotną rolę w procesie pobudzania oraz rozwoju przedsiębiorczości (Matusiak, Guliński, 2011). Aby wdrażać w życie tę rolę wspierania przedsiębiorczości, uczelnie muszą reagować na potrzeby różnych grup interesariuszy. Oczekuje się bowiem zaangażowania szkół we współpracę na poziomie lokalnym, regionalnym, a nawet globalnym (Schulte i in., 2013). W ostatnich latach, w nurcie społecznej odpowiedzialności biznesu (Corporate Social Responsibility, CSR), na znaczeniu zyskuje także dbałość o nawiązywanie i utrzymywanie relacji z interesariuszami.

W kontekście odpowiedzialności społecznej przedmiotem dyskursu stają się także szkoły wyższe (Maliszewski, Kacprzak, 2009; Piasecka, 2015). Powinnością uczelni jako instytucji życia publicznego staje się prowadzenie działalności, która oprócz edukacji i badań odpowiada na potrzeby społeczne i ekologiczne, tworząc tzw. wartość dodaną dla społeczeństwa i gospodarki (Białoń, Werner, 2012). Szkoły wyższe powinny więc dokładać wszelkich starań w kierunku przygotowania młodych ludzi do podejmowania różnego rodzaju aktywności i samodzielnego funkcjonowania na rynku, także jako przedsiębiorców (Wach, 2013; Brzozowska, 
Glinka, Postuła, 2014; Laszuk, 2016; Rachwał, Wach, 2016). Jednak nie jest to jedyna rola społecznie odpowiedzialnej uczelni. Jej władze powinny także wspierać działania w kierunku rozwoju i intensyfikacji współpracy z biznesem, nastawienie na nowość i innowacje (Osiri, McCarty, 2013). Badacze (Shattock, 2005; Multan, Wójcik-Augustyniak, 2016) twierdzą, że obecnie znaczenia nabiera elastyczność szkół wyższych i ich umiejętność dostosowywania do nowego modelu, wymuszającego na uczelniach bliższą współpracę z biznesem, proaktywność i zachowania innowacyjne. W tym kontekście podkreśla się także konieczność angażowania pracowników uczelni w jej rozwój poprzez poszukiwanie pomysłów na nowe usługi lub wprowadzanie wewnętrznych standardów jakości usług (Warwas, Gzik, Wiktorowicz, 2017).

Zmiany w ustawie Prawo o szkolnictwie wyższym z 2011 r. (Ustawa..., 2011) uporządkowały założenia związane $z$ działaniami komercjalizacyjnymi realizowanymi przez instytucje nauki i szkolnictwa wyższego w Polsce. Dostępność środków finansowych z Unii Europejskiej umożliwia przede wszystkim podejmowanie działań w zakresie tzw. komercjalizacji pośredniej (tzn. zakładanie spółek typu spin-off i spin-out, w których udziały mają uczelnie) (Cieślik i in., 2011). Jednak głównym mechanizmem realizacji komercjalizacji pozostają nadal tradycyjne metody współpracy z przedsiębiorstwami w zakresie wdrażania nowych rozwiązań poprzez ich sprzedaż lub licencjonowanie (tj. komercjalizacja bezpośrednia). Powiązania między przedsiębiorstwami a uczelniami w tym zakresie nabierają szczególnego znaczenia przy uwzględnieniu tempa zmian technologicznych oraz konieczności reagowania na te zmiany w kontekście funkcjonowania gospodarki opartej na wiedzy. Współpraca przedsiębiorców i naukowców przyczynia się bowiem do zwiększenia poziomu aplikacyjności badań naukowych, zaś poznawanie potrzeb przedsiębiorstw pozwala szkołom wyższym dostosowywać profile kształcenia studentów do potrzeb rynku pracy.

Badacze przedmiotu podkreślają, że transfer technologii z sektora badań naukowych do przedsiębiorstw (tj. sektora komercyjnego) przyczynia się w sposób bezpośredni do bogacenia się danego przedsiębiorstwa (Gibson, Stiles, 2000). Transferowi wiedzy i technologii towarzyszy ponadto wdrażanie dobrych praktyk oraz innowacyjnych technologii. W literaturze podkreśla się także, iż transferowi technologii między nauką a biznesem powinien towarzyszyć przepływ strumieni finansowych i ludzi oraz kreowanie popytu (Lange, Belinko, Kalligatsi, 2000).

Aby działania w zakresie wdrażania nowych rozwiązań technologicznych do praktyki przedsiębiorstw mogły być realizowane, musi być jednak spełnionych wiele uwarunkowań (Trzmielak, Grzegorczyk, 2014; Wu, Welch, Huang, 2015). Do czynników zewnętrznych (niezależnych od stron zaangażowanych w proces komercjalizacji) można przede wszystkim zaliczyć postęp technologiczny, wzrost 
znaczenia wiedzy i dostępu do informacji w gospodarce, specyfikę sektora oraz specyfikę danego kraju. Duże znaczenie dla procesu transferu wiedzy i technologii mają narodowy system innowacji, system prawny (ochrona własności intelektualnej), działalność instytucji wspierających, nakłady na rozwój technologii, świadomość społeczna oraz kultura innowacyjności (Szarucki, 2012; Gwarda-Gruszczyńska, 2013). Z kolei za determinanty zależne od uczestników procesu komercjalizacji uznano wizerunek przedsiębiorcy, konkurencyjność oferty oraz dostęp do ekspertów (Trzmielak, Grzegorczyk, 2014).

Istotną rolę w procesie komercjalizacji odgrywają również czynniki wewnątrzuczelniane (kultura organizacyjna), w tym biznesowe podejście uczelni do budowania relacji z przedsiębiorstwem oraz kompetencje wyspecjalizowanych jednostek odpowiedzialnych za komercjalizację, tzw. centrów transferu technologii (Plewa i in., 2013; Gwarda-Gruszczyńska, 2013). Istotnymi determinantami współpracy nauki i biznesu są ponadto kompetencje uczestników procesu komercjalizacji. Obecnie od przedstawicieli szkół wyższych oczekuje się bowiem nie tylko umiejętności związanych z prowadzeniem badań naukowych czy pracą dydaktyczną, lecz także, coraz częściej, kompetencji umożliwiających nawiązywanie i utrzymywanie trwałych relacji z interesariuszami, w tym z przedsiębiorcami.

\section{Próba identyfikacji kompetencji pracowników uczelni, będących determinantami podejmowania oraz realizacji współpracy $\mathrm{z}$ przedstawicielami przedsiębiorstw w procesie komercjalizacji - badanie własne}

\section{Kompetencje przedsiębiorcze naukowców - metodyka badania własnego}

Problematyka niniejszego artykułu dotyczy kompetencji naukowców, uczestników procesu komercjalizacji wyników badań naukowych. Przeprowadzone badanie miało na celu próbę identyfikacji kompetencji pracowników uczelni, będących determinantami podejmowania oraz realizacji współpracy z przedstawicielami przedsiębiorstw $\mathrm{w}$ procesie komercjalizacji. W celu realizacji badania empirycznego zastosowano metodę studium przypadku (case study), polegającą na studiowaniu wybranych złożonych obiektów, mających silne związki z otoczeniem, przy zastosowaniu różnorodnych źródeł informacji (tj. dokumenty, obserwacje, wywiady) (Patton, Appelbaum, 2003; Creswell, 2007; Baxter, Jack, 2008).

W wyniku przeglądu literatury oraz obserwacji ustalono, że powiązania między przedsiębiorstwami a szkołami wyższymi w zakresie komercjalizacji nabierają 
szczególnego znaczenia przy uwzględnieniu mającego obecnie miejsce wysokiego tempa zmian technologicznych oraz konieczności reagowania na te zmiany w kontekście funkcjonowania gospodarki opartej na wiedzy. Przedmiotem badania empirycznego stały się więc procesy komercjalizacji wyników badań naukowych, zachodzące w przedsiębiorstwach z branży technologicznej, oraz współpracująca $\mathrm{z}$ nimi uczelnia techniczna. W prezentowanym badaniu analizie poddano niektóre wyróżniki kompetencji przedsiębiorczych naukowców biorących udział w procesie komercjalizacji, tj. wiedzę, umiejętności, cechy osobowości, postawy oraz skłonność do podejmowania współpracy z przedsiębiorcami.

Badanie empiryczne zrealizowano przy zastosowaniu metody wywiadu. Wywiady przeprowadzono w Lublinie w 2017 r. z pięcioma osobami, tj. przedstawicielami dwóch lubelskich przedsiębiorstw uczestniczących we wdrażaniu innowacyjnych technologii ${ }^{1}$ oraz pracownikami Centrum Innowacji i Transferu Technologii Politechniki Lubelskiej, stanowiącym stronę pośrednika między uczelnią a przedsiębiorcami. Badania uzupełniono obserwacją bezpośrednią oraz analizą dokumentacji projektowej.

Celem prezentowanego badania była konceptualizacja modelu kompetencji przedsiębiorczych naukowców biorących udział w procesie komercjalizacji. Realizacja celu badań wymagała odpowiedniej budowy kwestionariusza wywiadu. Na podstawie literatury przedmiotu (Kwiatkowski, 2002; Oleksyn, 2006; Olearnik, 2007; Rakowska, 2007; Glinka, Gudkova, 2011), obserwacji oraz wcześniejszych badań (Jakubiak, Mażewska, 2014) wyodrębniono kilka głównych obszarów kompetencji, które uwzględniono przy budowie kwestionariusza wywiadu, tj.:

- wiedza ogólna i specjalistyczna (w tym nastawienie do jej poszerzania, orientacja badawcza),

- umiejętności,

- cechy osobowości i postawy,

- motywy podejmowanych działań,

- posiadane doświadczenia.

Zdaniem badaczy przedmiotu (Glinka, Gudkova, 2011; Trzmielak, Grzegorczyk, 2014), niektóre obszary kompetencyjne są szczególnie podatne na oddziaływanie czynników środowiskowych. Ponadto, na decyzje dotyczące współpracy wpływają także czynniki zewnętrzne (Szarucki, 2012; Gwarda-Gruszczyńska, 2013). Kwestionariusz uzupełniono więc o pytania dotyczące zewnętrznych

1 W badaniu wzięli udział prezesi dwóch lubelskich przedsiębiorstw, tj. Stachema Sp. z o.o., współpracująca z Politechniką Lubelską w zakresie syntezy sorbentów zeolitowych do związków ropopochodnych z popiołów lotnych będących odpadem w cementowni, oraz Sigma S.A., wdrażająca technologię związaną z produkcją maszyn do obróbki plastycznej. 
- środowiskowych determinant współpracy z biznesem oraz o pytania na temat trudności związanych z komercjalizacją wyników badań naukowych.

\section{Kompetencje przedsiębiorcze naukowców - konceptualizacja modelu}

Przedmiotem prezentowanego badania były kompetencje przedsiębiorcze naukowców, rozpatrywane w kontekście współpracy z przedsiębiorcami w procesie komercjalizacji wyników badań naukowych. Wyniki wcześniejszych badań (Jakubiak, Mażewska, 2014) wykazały, że naukowcy wyrażają zainteresowanie współpracą z przemysłem, jednak niewielu z nich prowadzi lub zamierza założyć własną firmę. Oczekiwania wobec współczesnych szkół wyższych oraz jej pracowników jednak sprawiają, że współpraca między uczelniami a biznesem staje się coraz bardziej oczekiwana. W podejmowaniu tego typu działań niewątpliwie mogą być pomocne kompetencje naukowców, których można w tym przypadku traktować jako przedsiębiorców wewnętrznych (Glinka, Gudkova, 2011). Kompetencje przedsiębiorcze mogą więc być rozpatrywane jako aktywność w kierunku współpracy z przedsiębiorcami w procesie komercjalizacji, a niekoniecznie w kierunku pracy na własny rachunek jako przedsiębiorca.

Celem prezentowanego badania była konceptualizacja modelu kompetencji przedsiębiorczych naukowców. Przeprowadzone badanie empiryczne wskazało obszary kompetencyjne, które, zdaniem badanych, mają wpływ na podejmowanie przez naukowców oraz efektywne realizowanie współpracy z przedstawicielami przedsiębiorstw w procesie komercjalizacji wyników badań.

Pierwszym analizowanym obszarem kompetencji była wiedza ogólna i specjalistyczna. Zdaniem badanych, niezbędna jest wiedza naukowca w zakresie:

- swoich mocnych stron i ograniczeń,

- ogólnych informacji o funkcjonowaniu biznesu (otoczeniu, sieci powiązań, zarządzaniu nimi; ogólna wiedza prawna i ekonomiczna),

- komercjalizacji,

- $\quad$ specjalistycznej wiedzy, związanej z daną technologią, realizowanymi badaniami.

Badani wskazali, że istotnym aspektem w kontekście wiedzy jest orientacja na temat tego, co już jest realizowane na rynku. Ich zdaniem, niekiedy naukowcom brak świadomości, jakie działania w zakresie rozwiązań technologicznych są już na etapie wdrożenia czy gotowego produktu. Badacze śledzą bowiem doniesienia z badań, literatury przedmiotu, ale nie zawsze mają wiedzę na temat rynku i działań przedsiębiorców. Zdarza się, że problem traktowany przez badacza jako potencjalna innowacja jest już wprowadzony na rynek i na nim sprzedawany.

Kolejnym analizowanym obszarem były umiejętności, które na potrzeby realizowanych badań podzielono na twarde (bezpośrednio związane 
z wykorzystywaniem posiadanej wiedzy na potrzeby realizowania zadań zawodowych) oraz miękkie, tj. umiejętności osobiste, społeczne, interpersonalne, komunikacyjne (Armstrong, 2005) (tabela 1). Za pożądane umiejętności twarde uznano m.in. umiejętność wykorzystywania specjalistycznych narzędzi, prowadzenia badań i powiązane z tym analizę, syntezę oraz wnioskowanie, a także umiejętność zauważania i wykorzystywania szans występujących w otoczeniu. Nie mniej istotne są kompetencje miękkie, w tym interpersonalne, ułatwiające nawiązywanie i utrzymywanie kontaktów oraz umiejętność uczenia się.

Tabela 1. Pożądane umiejętności naukowców

\begin{tabular}{|c|c|}
\hline \multicolumn{2}{|c|}{ Umiejętności } \\
\hline twarde & miękkie \\
\hline $\begin{array}{l}\text { - Umiejętność wykorzystania } \\
\text { specjalistycznych narzędzi } \\
\text { wykorzystywanych w praktyce biznesu } \\
\text { - Umiejętność prowadzenia badań } \\
\text { - Analiza, synteza, wnioskowanie } \\
\text { - Umiejętność zauważania } \\
\text { i wykorzystywania zmian szans } \\
\text { w otoczeniu } \\
\text { - Umiejętność poszukiwania informacji } \\
\text { - Zarządzanie własną karierą (jednoczesne } \\
\text { budowanie kariery naukowej } \\
\text { i wdrożeniowej) } \\
\text { - Umiejętność planowania i podejmowania } \\
\text { decyzji } \\
\text { Umiejętność organizowania czasu pracy } \\
\text { własnej }\end{array}$ & $\begin{array}{l}\text { - Umiejętność uczenia się, pogłębiania } \\
\text { wiedzy i rozwoju umiejętności } \\
\text { naukowo-badawczych } \\
\text { - Nawiązywanie kontaktów } \\
\text { - Praca w grupie } \\
\text { - Budowanie zespołu } \\
\text { - Umiejętności negocjacji i rozwiązywania } \\
\text { - Sytuacji konfliktowych } \\
\text { - Skuteczne komunikowanie się } \\
\text { i utrzymywanie trwałych relacji } \\
\text { - } \text { Ratworking) } \\
\text { - Szybkie dostosowywanie się do nowych } \\
\text { - } \text { sytuacji } \\
\text { - Ureatywne myślenie }\end{array}$ \\
\hline
\end{tabular}

Źródło: opracowanie własne na podstawie wyników przeprowadzonego badania.

Kolejnym analizowanym obszarem kompetencji naukowców były cechy osobowości i postawy (tabela 2). Respondenci twierdzili, że mają one niebagatelne znaczenie i często stanowią czynniki determinujące podjęcie współpracy między danym naukowcem a przedsiębiorcą. Ważne okazały się m.in. pasja, ciągłe dążenie do doskonalenia oraz odpowiedzialność i dotrzymywanie terminów (szczególnie podkreślane przez przedstawicieli biznesu). Za nieistotne uznano skłonność do podejmowania ryzyka, w literaturze uznane za jedną z podstawowych cech przedsiębiorcy działającego na własny rachunek, jednak rzadziej charakteryzującą intraprzedsiębiorców (Glinka, Gudkova, 2011). Analiza wyników badania wykazała niską skłonność naukowców do podejmowania ryzyka, które, zdaniem badanych, jest rozpatrywane z punktu widzenia projektów. Podejmują się oni raczej 
udziału w tych inicjatywach, które mają duże szanse powodzenia. Podobnie jest z przywództwem i zdolnością do inspirowania innych, które nie zostały uznane jedynie w przypadku liderów zespołów badawczych.

Tabela 2. Pożądane cechy naukowców-uczestników procesu komercjalizacji

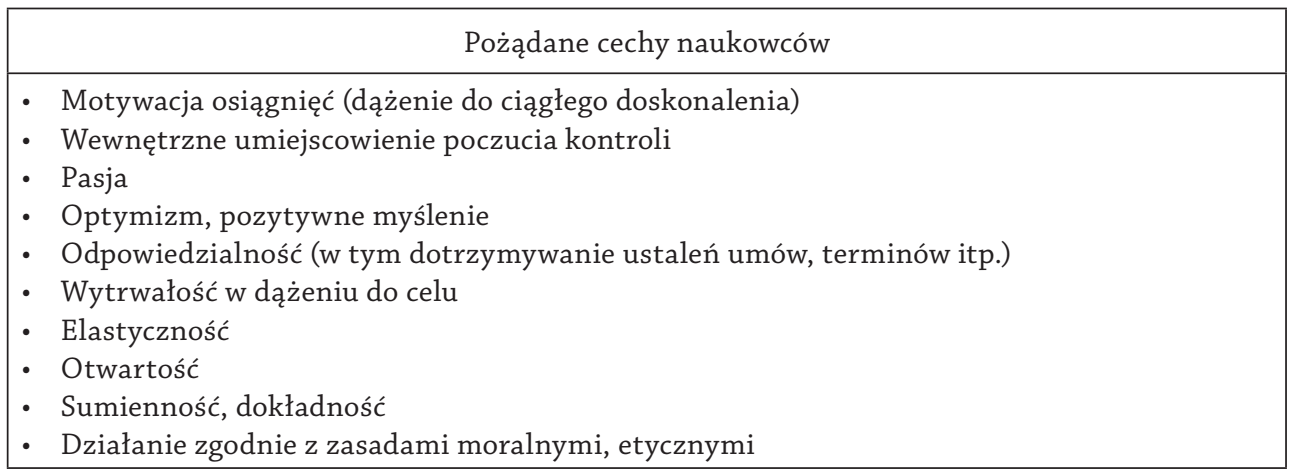

Źródło: opracowanie własne na podstawie wyników przeprowadzonego badania.

Interesujące było poznanie motywów, jakimi w podejmowaniu działań kierują się naukowcy. Zdaniem badanych są to:

- motywy finansowe,

- motywy intelektualne,

- wymiana doświadczeń i zdobywanie nowych,

- upowszechnianie osiągnięć,

- prestiż,

- możliwość dzielenia się wiedzą,

- sprawdzenie, czy wynik badań ma charakter aplikacyjny,

- rozwój zawodowy, naukowy.

W literaturze przedmiotu podkreśla się istotny wpływ doświadczeń danej jednostki na podejmowanie aktywności w kierunku przedsiębiorczości. Z przeprowadzonego badania jednak nie wynika, że doświadczenie jest niezbędne w przypadku naukowców zamierzających podjąć współpracę z biznesem. Przypadki te, zdaniem badanych, należy rozpatrywać indywidualnie, niekiedy przydaje się doświadczenie we współpracy z przemysłem lub projektowe, często jednak już pierwsze kontakty dają szansę nawiązania efektywnej współpracy.

Przedstawione w niniejszym artykule badanie miało na celu konceptualizację modelu kompetencji przedsiębiorczych naukowców-uczestników procesu komercjalizacji. W uproszczeniu przedstawiono je na rysunku 1. Na kompetencje przedsiębiorcze składają się więc wiedza, umiejętności, cechy osobowości i postawy, motywy oraz doświadczenie. 
Rysunek 1. Model kompetencji przedsiębiorczych pracowników naukowych

$$
\begin{aligned}
& \text { Wiedza } \\
& \text { - o sobie } \\
& \text { - ogólna } \\
& \text { - o biznesie } \\
& \text { - specjalistyczna }
\end{aligned}
$$
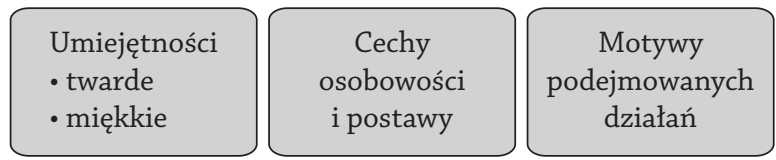

Doświadczenie

Źródło: opracowanie własne na podstawie wyników przeprowadzonego badania.

Analizując determinanty współpracy naukowców z przedsiębiorcami w procesie komercjalizacji, warto także nawiązać do czynników związanych ze środowiskiem uczelnianym. Zdaniem badanych, kluczowe znaczenie ma kultura organizacyjna uczelni i wydziału, odznaczająca się otwartością i nastawieniem na współpracę, brak utrudnień administracyjno-organizacyjnych, dostępność wsparcia ze strony uczelni (działalność centów transferu technologii). Istotne znaczenie mają także kompetencje oraz nastawienie zwierzchników i władz (dziekana, rektora) do współpracy. Nieco mniejsze znaczenie przypisano zainteresowaniem współpracą ze strony przemysłu, ponieważ niejednokrotnie to naukowcy wychodzą z inicjatywą i poszukują partnerów z biznesu (podejście podażowe do komercjalizacji).

Badanych poproszono także o wskazanie trudności związanych z procesem komercjalizacji. Można je podzielić na kilka grup, tj. na:

- instytucjonalne wewnątrzuczelniane (wymagania odnośnie do zaangażowania pracowników naukowych, np. wprowadzenie zajęć dydaktycznych; podział środków, zbyt wysokie narzuty wewnętrzne),

- instytucjonalne zewnętrzne (formalnoprawne, trudności związane z uzyskaniem praw do wyników badań),

- finansowanie badań naukowych (trudności z pozyskaniem grantów),

- zasady uzyskiwania awansu zawodowego naukowca (np. brak możliwości realizacji habilitacji wdrożeniowej),

- brak chęci angażowania się naukowca w projekty, dzięki którym nie ma możliwości zdobycia awansu (doktoratu lub habilitacji).

\section{Podsumowanie}

Przedmiotem niniejszego artykułu były determinanty podejmowania i utrzymywania współpracy między naukowcami a przedsiębiorcami w procesie komercjalizacji wyników badań naukowych. W warunkach gospodarki opartej na 
wiedzy współpraca nauki i biznesu wydaje się być niezbędna, a także korzystna dla obu stron. Jednocześnie w literaturze przedmiotu podkreśla się brak tego typu współpracy lub jej niewystarczający poziom (Matusiak, Guliński, 2011; Gwarda-Gruszczyńska, 2013; Trzmielak, Grzegorczyk, 2014).

Wyniki przedstawionego w niniejszym artykule badania pozwoliły na konceptualizację modelu kompetencji przedsiębiorczych naukowców-uczestników procesu komercjalizacji. Przeprowadzone wywiady pozwoliły ustalić, które kategorie kompetencji można uznać za istotne determinanty podejmowania przez naukowca współpracy z przedstawicielami przedsiębiorstw. Jednocześnie badani podkreślali, że kompetencje nie są jedynym czynnikiem determinującym tego typu współpracę i jej skuteczność. Niezmiernie ważna jest bowiem kultura organizacyjna uczelni. Klimat aktywności i przedsiębiorczości panujący w instytucji oraz akceptacja aktywności przez władze sprawiają, że pracownicy chętniej podejmują aktywności w kierunku wspólnych projektów.

Omawiane badanie pozwoliło także na wyodrębnienie kilku obszarów trudności we współpracy na linii nauka-biznes. Wyniki potwierdzają doniesienia literatury przedmiotu w tym zakresie. E. Gwarda-Gruszczyńska (2013) zalicza do głównych przyczyn braku współpracy brak funduszy kapitałowych oraz wysokie koszty innowacji. Podobne aspekty podkreślali D.M. Trzmielak i M. Grzegorczyk (2014), którzy jako rozwiązanie tych trudności sugerują budowanie zaufania, współpracy i partnerstwa poprzez prowadzenie kampanii edukacyjnych, promujących wspólne inicjatywy oraz działania proinnowacyjne. Sposobem zachęcenia do współpracy obu stron może być także propagowanie wspólnych projektów badawczych oraz kursy i szkolenia (Gwarda-Gruszczyńska, 2013).

Prezentowane badanie stanowi przyczynek do dyskusji nad kompetencjami przedsiębiorczymi naukowców, ale nie wyczerpują tematu. Ustalony w wyniku przeprowadzonych analiz kierunek badań powinien być kontynuowany w przyszłości. Autorka pragnie przeprowadzić badania empiryczne zwłaszcza w kierunku weryfikacji wyłonionego modelu kompetencyjnego. Warto przeprowadzić badania wśród reprezentatywnej próby respondentów, zarówno pracowników naukowych jak i współpracujących z nimi przedsiębiorców. Interesujące byłyby także wyniki analiz efektywności tej współpracy.

\section{Bibliografia}

Antonacopoulou, E.P., Fitzgerald, L. (1996). Reframing competency in management development. Human Resource Management Journal, 6(1), 27-48.

Argyle, M. (1967). The Psychology of Interpersonal Behaviour. Harmondsworth: Penguin. 
Armstrong, M. (2005). Zarzq̨dzanie zasobami ludzkimi. Kraków: Oficyna Ekonomiczna. Baxter, P., Jack, S. (2008). Qualitative Case Study Methodology: Study Design and Implementation for Novice Researchers. The Qualitative Report, 13(4), 544-559.

Białoń, L., Werner, E. (2012). Społeczna odpowiedzialność szkoły wyższej w kontekście jej wizerunku. Nauka i Szkolnictwo Wyższe, 1(39), 142-161.

Boyatzis, R.E. (1982). The Competent Manager: A Model for Effective Performance. New York: John Wiley \& Sons.

Brzozowska, A., Glinka, B., Postuła, A. (2014). Rola uniwersytetu w kształtowaniu intencji przedsiębiorczych. Horyzonty Wychowania, 13(26), 51-72.

Cieślik, J., Matusiak, K.B., Guliński, J., Skala-Poźniak, A. (2011). Edukacja dla przedsiębiorczości akademickiej. Poznań-Warszawa: Polska Agencja Rozwoju Przedsiębiorczości.

Creswell, J.W. (2007). Qualitative Inquiry and Research Design: Choosing among Five Approaches. Second Edition. Thousand Oaks, CA: Sage Publications Inc.

Dyduch, W. (2004). Wpływ kapitału społecznego na przedsiębiorczość i efektywność organizacji. W: M. Juchnowicz (red.), Kapitał ludzki a kształtowanie przedsiębiorczości. Warszawa: Poltext, 44-55.

Gibson, D., Stiles, Ch.E. (2000). Technopolies, technology transfer and global network, entrepreneurship. W: P. Conceição, D.V. Gibson, M.V. Heitor, S. Shariq (red.), Science Technology and Innovation Policy. Opportunity and Challenges for the Knowledge Economy. London: Quorum Books.

Glinka, B., Gudkova, S. (2011). Przedsiębiorczość. Warszawa: Wolters Kluwer business. Gwarda-Gruszczyńska, E. (2013). Uwarunkowania procesów komercjalizacji nowych technologii w przedsiębiorstwach polskich i zagranicznych. Zeszyty Uniwersytetu Szczecińskiego. Ekonomiczne Problemy Usług, 795(109), 139-160.

Jakubiak, M., Mażewska, M. (2014). Analiza możliwości wdrożenia międzyuczelnianego programu inkubowania i rozwoju innowacyjnych firm $w$ branżach inteligentnych specjalizacji województwa lubelskiego. Lublin: Urząd Marszałkowski Województwa Lubelskiego w Lublinie.

Juceviciene, P., Lepaitte, D. (2004). Competences as derived from acidity: The problem of their level correspondence. Kaunas: Kaunas University of Technology, Institute of Educational Studies.

Juchnowicz, M. (2004). Kapitał ludzki a kształtowanie przedsiębiorczości. Warszawa: Poltext.

Kwiatkowski, S. (2002). Intellectual Entrepreneurship. Warszawa: Wydawnictwo Naukowe PWN.

Lange, D., Belinko, K., Kalligatsi, K. (2000). Building successful technology commercialization teams: Pilot empirical support for the theory of cascading commitment. Journal of Technology Transfer, 25, 169-180.

Laszuk, M. (2016). Entrepreneurship Education - A Handful of Experiences. Edukacja Ekonomistów i Menedżerów. Problemy. Innowacje. Projekty, 42, 99-109. 
Maliszewski, T., Kacprzak, A. (2009). Etyczni - ekonomiczni - efektywni. Odpowiedzialne kształcenie menedżerów przez szkoły wyższe. Nauka i Szkolnictwo Wyższe, 2(34), 44-59.

Matusiak, K.B., Guliński, J. (2011). Kierunki doskonalenia systemu transferu technologii i komercjalizacji wiedzy w Polsce - zadania dla rządu i administracji centralnej. Zeszyty Naukowe Uniwersytetu Szczecińskiego. Ekonomiczne Problemy Usług, 64, 27-57.

Matusiak, K.B., Zasiadły, K. (2005). Rekomendacje dla Polski. W: J. Guliński, K. Zasiadły (red.), Innowacyjna przedsiębiorczość akademicka - światowe doświadczenia. Warszawa: Polska Agencja Rozwoju Przedsiębiorczości, 145-148.

Multan, E., Wójcik-Augustyniak, M. (2016). Research Methodology of Entrepreneurship and Innovativeness of Higher Education Institutions. Edukacja Ekonomistów i Menedżerów. Problemy. Innowacje. Projekty, 4(42), 83-98.

Olczak, A., Kołodziejczyk-Olczak, I. (red.) (2006). Leksykon zarzqdzania. Łódź: Wydawnictwo Wyższej Szkoły Humanistyczno-Ekonomicznej w Łodzi.

Olearnik, J. (2007). Obszary i formy działań dla wykształcenia przedsiębiorczego absolwenta. W: P. Wachowiak, M. Dąbrowski, B. Majewski (red.), Kształtowanie postaw przedsiębiorczych a edukacja ekonomiczna. Warszawa: Fundacja Promocji i Akredytacji Kierunków Ekonomicznych, 114-119.

Oleksyn, T. (2006). Zarządzanie kompetencjami. Teoria i praktyka. Kraków: Oficyna Ekonomiczna.

Osiri, J.K., McCarty, M.M. (2013). Entrepreneurial culture in institutions of higher education: Impact on academic entrepreneurship. Journal of Entrepreneurship Education, 16, Special Issue, 4-11.

Patton, E., Appelbaum, S.H. (2003). The Case for Case Studies in Management Research. Management Research News, 26(5), 60-71.

Piasecka, A. (2015). Społeczna odpowiedzialność uczelni w kontekście wewnętrznego zapewnienia jakości. Prace Naukowe Uniwersytetu Ekonomicznego we Wrocławiu, 378, 309-319.

Plewa, C., Korff, N., Johnson, C., Macpherson, G., Baaken, Th., Rampersad, G.C. (2013). The evolution of university-industrylinkages - A framework. Journal of Engineering and Technology Management, 30(1), 21-44.

Poznańska, K. (2014). Przedsiębiorczość akademicka - cechy i znaczenie w gospodarce światowej i polskiej. Studia Ekonomiczne. Zeszyty Naukowe Uniwersytetu Ekonomicznego w Katowicach, 183, 164-172.

Prien, E.P. (1977). The Function of Job Analysis in Content Validation. Personnel Psychology, 30(2), 167-174.

Rachwał, T., Wach, K. (2016). Badanie intencji przedsiębiorczych młodego pokolenia: wyniki ankietyzacji wśród studentów kierunków nieekonomicznych. Przedsiębiorczość - Edukacja, 12, 405-415.

Rakowska, A. (2007). Kompetencje menedżerskie kadry kierowniczej we wspótczesnych organizacjach. Lublin: Wydawnictwo Uniwersytetu Marii Curie-Skłodowskiej. 
Rakowska, A., Sitko-Lutek, A. (2000). Doskonalenie kompetencji menedżerskich. Warszawa: Wydawnictwo Naukowe PWN.

Sajkiewicz, A. (2004). Zarządzanie kapitałem ludzkim a przedsiębiorczość - wyzwania XXI wieku. W: M. Juchnowicz (red.), Kapitał ludzki a kształtowanie przedsiębiorczości. Warszawa: Poltext, 13-24.

Schulte, P., Živković, D., Graef, M., Vadnjal, J., Trisca, G., Mihajlović, I., Pavlov, D., Živković, Ž., Dimitrova, M., Zečić, D., Halebić, J., Tantau, A. (2013). Resita network: Academic entrepreneurship and innovation network of South Eastern European universities: An example of successful networking in entrepreneurship and innovation at academic level. Serbian Journal of Management, 8(1), 117-130.

Shattock, M. (2005). European universities for entrepreneurship: Their role in the Europe of knowledge. The theoretical context. Higher Education Management and Policy, 17(3), 13-25.

Sitko-Lutek, A. (red.) (2007). Polskie firmy wobec globalizacji. Luka kompetencyjna. Warszawa: Wydawnictwo Naukowe PWN.

Stawasz, E. (2007). Stymulowanie przedsiębiorczości środowiska naukowego w Polsce. Zeszyty Naukowe Uniwersytetu Szczecińskiego. Ekonomiczne Problemy Usług, 453(8), 265-276.

Szarucki, M. (2012). Analiza czynników determinujących decyzję o komercjalizacji wyników badań naukowych (na przykładzie Niemiec i Szwecji). Rekomendacje dla Polski. Zeszyty Naukowe Wyższej Szkoły Ekonomii i Informatyki w Krakowie, 8, 205-222.

Timmons, J.A. (1999). New Venture Creation: Entrepreneurship for the $21^{\text {st }}$ Century. Boston: Irwin/McGraw-Hill.

Trzmielak, D.M., Grzegorczyk, M. (2014). Transfer wiedzy i technologii z uczelni do biznesu - determinanty współpracy przedsiębiorstw i naukowców. Handel Wewnętrzny, 5(352), 293-306.

Ustawa z dnia 18 marca 2011 r. o zmianie ustawy - Prawo o szkolnictwie wyższym, ustawy o stopniach naukowych i tytule naukowym oraz o stopniach i tytule w zakresie sztuki oraz o zmianie niektórych innych ustaw, Dz.U. Nr 84, poz. 455. http://prawo.sejm.gov.pl/isap.nsf/DocDetails.xsp?id=WDU20110840455 (10.11.2017).

Wach, K. (2013). Edukacja na rzecz przedsiębiorczości wobec współczesnych wyzwań cywilizacyjno-gospodarczych. Przedsiębiorczość - Edukacja, 9, 246-257.

Warwas, I., Gzik, M., Wiktorowicz, J. (2017). Badanie opinii i oczekiwań pracowników - studium przypadku uczelni wyższej. Edukacja Ekonomistów i Menedżerów. Problemy. Innowacje. Projekty, 1(43), 85-101.

Wernerfelt, B. (1984). A Resource-Based View of the Firm. Strategic Management Journal, 5, 171-180.

Wu, Y., Welch, E.W., Huang, W.L. (2015). Commercialization of university inventions: Individual and institutional factors affecting licensing of university patents. Technovation, 36-37, 12-25. 


\section{Summary}

\section{Impact of Scientists' Entrepreneurial Competencies on Business-Science Cooperation}

At present, business-science cooperation has been gaining significance. Changes in the role of universities necessitate the establishment of collaboration with business environment, including one aimed at the commercialization of research results. The subject matter of the paper pertains to scientists' entrepreneurial competencies in the context of cooperation between the academia and entrepreneurs. The objective of the study is to identify competencies of scientists determining their involvement in cooperation with businesses. Empirical studies were conducted in Lublin in 2017 by means of a case study method, direct observations, and interviews. The analysis of results enabled entrepreneurial competence model of scientists (active participants in commercialization) to be conceptualized.

Keywords: scientists' entrepreneurial competencies, commercialization of research results, business-science cooperation, role of university, universities' stakeholders.

\section{Dr Monika Jakubiak}

Doktor nauk ekonomicznych, adiunkt na Wydziale Ekonomicznym Uniwersytetu Marii Curie-Skłodowskiej w Lublinie. W latach 2002-2014 koordynator Biura Karier Politechniki Lubelskiej. Współautorka wniosków i koordynator czterech projektów finansowanych z Europejskiego Funduszu Społecznego, wykonawca w dwóch projektach badawczych, koordynator UMCS w międzynarodowym projekcie realizowanym w ramach Programu Erasmus+. Realizator wielu innych projektów jako doradca, konsultant oraz trener (ponad 4 tys. godzin szkoleniowych dla różnych grup odbiorców). Naukowo zajmuje się badaniami w zakresie przedsiębiorczości, kompetencji, oczekiwań pracodawców, rynku pracy. Jest autorką ponad 50 publikacji naukowych z zakresu zarządzania, przedsiębiorczości, doskonalenia zawodowego, rynku pracy. Wyniki swoich badań prezentuje podczas licznych konferencji naukowych w Polsce i za granicą. 


\section{Mgr Paweł Chrapowicki}

Doktorant na Wydziale Zarządzania Uniwersytetu Warszawskiego. Zajmuje stanowisko dyrektora Centrum Innowacji i Transferu Technologii Politechniki Lubelskiej oraz od 2008 r. jest zaangażowany we wspieranie internacjonalizacji MSP. Ma doświadczenie w zarządzaniu prawami własności intelektualnej oraz jest zaangażowany $\mathrm{w}$ doradztwo $\mathrm{w}$ zakresie innowacyjności przedsiębiorstw. Uczestniczył w programie stypendialnym TOP 500 Innovators na Uniwersytecie Kalifornijskim w Berkeley. Jego zainteresowania badawcze obejmują tematy współpracy przedsiębiorstw z naukowcami oraz zarządzaniem własnością intelektualną. 